\title{
TMPO wt Allele
}

National Cancer Institute

\section{Source}

National Cancer Institute. TMPO wt Allele. NCI Thesaurus. Code C105101.

Human TMPO wild-type allele is located in the vicinity of 12 q22 and is approximately 34 $\mathrm{kb}$ in length. This allele, which encodes both lamina-associated polypeptide 2, isoform alpha and lamina-associated polypeptide 2, isoforms beta/gamma proteins, is involved in the maintenance of nuclear structure. Mutation of the gene is associated with cardiomyopathy dilated type $1 \mathrm{~T}$. 